\title{
Mining Sorghum Biodiversity-Potential of Dual-Purpose Hybrids for Bio-Economy
}

\author{
Adnan Kanbar ${ }^{1, *(\mathbb{C}, \text { Noemi Flubacher }}{ }^{1}$, Jiří Hermuth ${ }^{2}$, Klára Kosová ${ }^{2}$, Thomas Horn ${ }^{3}$ and Peter Nick ${ }^{1}$ \\ 1 Molecular Cell Biology, Botanical Institute, Karlsruhe Institute of Technology, 76131 Karlsruhe, Germany; \\ noemi-flubacher@gmx.de (N.F.); peter.nick@kit.edu (P.N.) \\ 2 Gene Bank, Department of Plant Stress Biology and Biotechnology, Crop Research Institute, \\ 16106 Prague, Czech Republic; hermuth@vurv.cz (J.H.); kosova@vurv.cz (K.K.) \\ 3 Independent Researcher, 76767 Hagenbach, Germany; drgirasol@apartofnature.de \\ * Correspondence: adnan.kanbar@kit.edu
}

Citation: Kanbar, A.; Flubacher, N.; Hermuth, J.; Kosová, K.; Horn, T.; Nick, P. Mining Sorghum Biodiversity-Potential of DualPurpose Hybrids for Bio-Economy. Diversity 2021, 13, 192. https:// doi.org/10.3390/d13050192

Academic Editors: Michael Wink and Mario A. Pagnotta

Received: 9 April 2021

Accepted: 27 April 2021

Published: 29 April 2021

Publisher's Note: MDPI stays neutral with regard to jurisdictional claims in published maps and institutional affiliations.

Copyright: (c) 2021 by the authors. Licensee MDPI, Basel, Switzerland. This article is an open access article distributed under the terms and conditions of the Creative Commons Attribution (CC BY) license (https:// creativecommons.org/licenses/by/ $4.0 /)$.

\begin{abstract}
Sweet, grain, and dual-purpose sorghums differ in a number of important traits, including biomass production, total solutes in the stem juice, and sugar accumulation across the stem. Ten dual-purpose hybrids, two sweet genotypes, and two grain landraces of sorghums were characterized under temperate environmental conditions to determine their potential for bioethanol production. Five sorghum hybrids (Ganymed, Hannibal, Tarzan, Merlin, and Zerberus) performed better with respect to cane yield, juice yield, potential sugar, and ethanol yields compared to sweet and grain genotypes. While the sweet genotype KIT1 produced the highest sugar concentration in the stem, the lowest concentration was produced by the grain landrace Razinieh. The study showed that plant height, leaf number, leaf weight, cane yield, and juice yield were positively correlated with the sugar yield in fresh stalk. Sugar accumulation was higher in the central internodes of all genotypes. Clustering analysis showed that sweet genotypes are located more closely to dual-purpose hybrids than grain landraces. We discuss the results with respect to the potential of dual-purpose sorghum hybrids for bio-economy in Germany.
\end{abstract}

Keywords: sorghum (grain; sweet; dual-purpose); sugar accumulation; stem internode; bio-economy

\section{Introduction}

The global population growth consequently leads to an increase in food, fodder, and energy demand in form of fossil fuel, and therefore exacerbates the negative effects of global climate change further [1]. As one strategy to contain the excess of carbon dioxide, the use of natural carbon sinks (most efficient for the preferential use of plants with $\mathrm{C}_{4}$ photosynthesis) allows absorbing ambient carbon dioxide for transformation into biomass [2]. Further, effects of greenhouse gas emissions can be mitigated by a moderate shift of fossil energy to biomass-derived renewable energy [3]. However, the usage of food crops for bioethanol production is progressively assessed critically. To circumvent this "no food for fuel" dilemma, the use of plants that do not compete with food crops, i.e., those able to grow on marginal lands, is a promising and strategic approach [4].

Sorghum (Sorghum bicolor L. Moench) is the world's fifth most important cereal crop after maize, rice, wheat, and barley due to its multipurpose economically important yields such as food, fodder, bioethanol, and further industrial uses [5,6]. The aspect that sorghum, as a $\mathrm{C}_{4}$ photosynthesis plant, has a high efficiency in terms of absorbing ambient atmospheric carbon dioxide and its transformation into biomass, underlines its multipurpose versatility and potential for bio-economy [7]. Besides the high yield of biomass, several advantages, such as low input requirements, good adaptation to the constraints, characteristic for marginal lands, and rich genomic resources, led to the use of sorghum for fuel [8]. In contrast to many other sources, all parts of sorghum-its biomass, its grain, and its sugary juice from the stem — can be used for ethanol production [9]. 
Sorghum varieties can be divided into four major classes based on the major forms of use: sweet, grain, fodder, and high biomass types $[10,11]$. Grain sorghum is an important staple crop for its dry stem and gluten-free grains, most popular in Africa and China [12,13], as also observed in some ancient wheats of the Mediterranean Basin [14]. Sweet sorghum (S. bicolor ssp. bicolor) is well suited for plant-based bioethanol production, due to its sugary stalk [15]. However, its use has not yet been implemented in many developing countries, as these varieties are currently not available for small- and large-scale farmers [16]. "Ideal" varieties should feature and combine certain traits, such as high yield of grain and biomass and high stem sugar content, each in an acceptable amount, to allow use as dual-purpose crops $[17,18]$.

Sweet and grain sorghum varieties differ in several important traits like plant height, grain, biomass production, and accumulation of stem sugar and juice [19]. Sweet sorghum is a natural variant of the common grain sorghum, featuring thicker stems acting as primary sink tissue for synthesized sugar during flowering and translocation into seeds during seed filling [20]. Due to its ability to produce high biomass under adverse conditions, sweet sorghum has been considered as a source of raw material for second-generation bioethanol and lignocellulosic feedstocks in temperate areas like Germany [21,22]. In contrast, grain sorghum stores carbohydrates as starch in seeds [12]. Unlike grain sorghum, all sweet sorghum genotypes are classified within S. bicolor ssp. bicolor [23].

Previous research investigating the accumulation of sucrose in sweet sorghum stems indicated that sucrose accumulation begins with the start of the reproductive phase [24]. Interestingly, however, it could be shown by genetic analysis that grain and sweet sorghum share striking genetic similarities, where genotypes of both sorghum types clustered together based on the geography of origin rather than with respect to sugar-related differences [23]. Nevertheless, key differences between sweet and grain sorghum were found in regulatory genes and sugar metabolism genes, which are likely to play major roles in stem sugar accumulation, despite the high genetic similarity at structural levels [25]. Both, sweet and grain sorghums accumulated sugar in higher concentrations in central internodes, while accumulating more weight in the basal internodes [26]. Compared to the grain types, sweet genotypes double or even triple the sugar concentration in all internodes, with the highest amounts of sugar in the central internodes. Juice volume can increase by six- to ninefold [27].

Therefore, the objectives of the study were: (1) to characterize dual-purpose sorghum hybrids and determining their potential for use as source of bioethanol production and (2) to investigate major differences between sweet and grain sorghum in terms of stemsugar accumulation.

\section{Materials and Methods}

\subsection{Plant Materials}

For this study, 14 sorghum genotypes of S. bicolor L. Moench were chosen and grouped according to their use in agricultural practice (Table 1). These included sweet varieties (KIT1 and So-29), grain landraces (Razinieh and Ruzrok), and dual-purpose hybrids (Zerberus, Juno, Bulldozer, Ganymed, Phoenix, Hannibal, Freya, Merlin, Sole, and Tarzan). KIT1 is a sweet sorghum genotype developed by us using pedigree selection. Razinieh is an improved Syrian landrace whose grain productivity was enhanced by bulk breeding [19]. Ruzrok is a grain sorghum variety that was bred from a landrace collected by V. Holubec in the Bílé Karpaty region in Moravia, Czech Republic [28]. The sweet variety So-29 was maintained by Crop Research Institute, Prague, Czech Republic, and released in 1971. All hybrids used in this study were bred by KWS company (KWS SAAT SE \& Co. KGaA, Einbeck, Germany) with the targets of high yield and high disease tolerance for production of grain and biomass. 
Table 1. List of genotypes used in this study, their agronomic group, type, origin, and resistant to lodging.

\begin{tabular}{|c|c|c|c|c|c|}
\hline ID & Cultivars & Group & Lodging & Type & Origin \\
\hline 9472 & Zerberus & Grain, biomass & Resistant & S. bicolor $x$ S. bicolor & KWS, Germany \\
\hline 9473 & Juno & Grain, biomass & Resistant & S. bicolor $x$ S. bicolor & KWS, Germany \\
\hline 9474 & Bulldozer & Grain, biomass & Resistant & S. bicolor $x$ S. bicolor & KWS, Germany \\
\hline 9475 & Ganymed & Grain, biomass & Resistant & S. bicolor $x$ S. bicolor & KWS, Germany \\
\hline 9576 & Phoenix & Grain, biomass & Resistant & S. bicolor $x$ S. bicolor & KWS, Germany \\
\hline 9477 & Hannibal & Grain, biomass & Resistant & S. bicolor $x$ S. bicolor & KWS, Germany \\
\hline 9478 & Freya & Grain, biomass & susceptible & S. bicolor $x$ S. sudanense & KWS, Germany \\
\hline 9479 & Merlin & Grain, biomass & Resistant & S. bicolor $x$ S. bicolor & KWS, Germany \\
\hline 9480 & Tarzan & Grain, biomass & Resistant & S. bicolor $x$ S. bicolor & KWS, Germany \\
\hline 9481 & Sole & Grain, biomass & susceptible & S. bicolor $x$ S. sudanense & KWS, Germany \\
\hline 9145 & Razinieh & Grain & Moderate & Landrace & Syria \\
\hline 9482 & Ruzrok & Grain & Moderate & variety & Czech Republic \\
\hline 9483 & So-29 & Sweet, biofuel & susceptible & variety & Czech Republic \\
\hline 9484 & KIT1 & Sweet, biofuel & Resistant & Elite line & KIT, Germany \\
\hline
\end{tabular}

\subsection{Plant Cultivation}

Plants were grown at the Botanical Garden of Karlsruhe Institute of Technology (Karlsruhe, Germany) during the summer (May-August) of 2018. Karlsruhe is located in the Rhine Valley of Southeast of Germany (latitude: $49^{\circ} 0^{\prime} 24.8004^{\prime \prime} \mathrm{N}$, longitude: $8^{\circ} 24^{\prime} 13.1508^{\prime \prime} \mathrm{E}$ ), with an average elevation of $119 \mathrm{~m}$ above sea level (based on the World Geodetic System 1984 datum). Temperatures ranged from around $-1{ }^{\circ} \mathrm{C}$ during winter to $26^{\circ} \mathrm{C}$ during summer in a temperate oceanic climate. Seeds were planted in three randomized experimental blocks, each block containing one plot of six adjacent rows of $5.0 \mathrm{~m}$ length for each sorghum genotype. The two outer rows of each plot served as buffers, while all measured parameters were taken from the plants in the two middle rows. A spacing of $60 \mathrm{~cm}$ between rows and $25 \mathrm{~cm}$ between individuals within rows was maintained. In total, 80 seeds were planted in each row and thinned manually to 20 individuals per row at the two-leaf stage. Environmental factors such as temperature and rainfall were monitored during the experiment and are presented as monthly average values in Supplementary Table S1. Based on soil analysis, $100 \mathrm{~g} / \mathrm{m}^{2}$ organic fertilizer (Hauert Hornoska®Special, Nürnberg, Germany) and 90:60:40 kg/ha of NPK were added.

\subsection{Phenotyping of Plants and Internodes}

As recommended by previous studies, sorghum plants were harvested at dough stage (the seeds are still soft and immature, and embryogenesis was completed), when optimal sugar concentration is mostly stored in stem sink tissue as reported $[19,26,29]$ during the month of August. For analysis, from each replicate, five plants located in the center of a plot were sampled randomly for recording plant height $(\mathrm{cm})$, leaf number, internode number, fresh leaf weight ( $\mathrm{g} /$ plant), cane yield ( $\mathrm{t} / \mathrm{ha})$, juice yield $(\mathrm{kl} / \mathrm{ha})$, bagasse yield ( $\mathrm{t} / \mathrm{ha})$, and sugar concentration $\left({ }^{\circ} \mathrm{Brix}\right)$. The theoretical ethanol yield was estimated as 40 liters per ton of cane yield [30]. Sugar yield ( $t /$ ha) and percentage was estimated using formulas of [31].

In addition to entire plants, the following measurements were conducted in each internode individually: internode length $(\mathrm{cm})$, internode bagasse weight $(\mathrm{g})$, internode juice volume $(\mathrm{mL})$, internode weight $(\mathrm{g})$, and sugar concentration ( ${ }^{\circ}$ Brix). As to quantify the juice yield, and to measure the sugar concentration of the juice directly after harvest, a conventional cane crusher (Sugarcane Juicer 110LBS/H, VEVOR, Shanghai, China) was used. Sugar concentration as ${ }^{\circ}$ Brix was recorded with a manual refractometer (Model PAL, Atago Co. Ltd., Tokyo, Japan) for each individual cane. 


\subsection{Statistical Analysis}

Data were subjected to individual ANOVA for different characters in order to assess the variability among the genotypes using PROC ANOVA in SAS version 9.4 (SAS Institute Inc., Cary, NC, USA). Mean comparisons were separated with least significant difference (LSD) at $5 \%$ level of significance. Additionally, grand mean and coefficient of variation as percentage (C.V.\%) were recorded for each measured trait individually. To estimate the degree of linear association between the studied traits, the simple correlation coefficient ( $r$ ) was computed using the standard formula of [32]. The significance of correlation coefficients was tested at $\mathrm{n}-2$ degrees of freedom on a " $\mathrm{t}$ " table from Fisher and Yates at $5 \%$ and $1 \%$ significance levels.

The multi-collinearity in path analysis was investigated to avoid bias in the decisionmaking process regarding the partial effect of independent variables on the dependent variable. For this purpose, the method of tolerance index (TOL) was employed. The procedure of computing TOL is first to make each independent variable as the criterion variable regressing against all other explanatory variables. Then TOL is calculated as following: TOL $=1-R^{2}$, where, $R^{2}=$ coefficient of multiple determination. TOL is simply the unexplained variance. A small TOL denotes high multi-collinearity [33]. As cut-off for TOL, we used a value of 0.2. Path coefficient analysis was carried out using the phenotypic correlation coefficients to determine the direct and indirect effects of morphological characters on sugar yield. No independent trait caused multi-collinearity. Morphological data were standardized using Minitab 17 (Minitab Ltd., Coventry, UK), and a Euclidean distance matrix was generated according to [34] with Minitab 17 (Minitab Ltd., Coventry, UK). General agglomerative hierarchical clustering was conducted with Average linkage method and subsequently used to plot a dendrogram. The principal component analysis (PCA) was applied to plot the relationship between distance matrix elements with respect to their first two principal components, using Minitab 17.

\section{Results}

\subsection{Agro-Morphological Descriptive Analysis}

The analysis of variance using a randomized complete block design showed significant variation $(p<0.05)$ for all 10 quantitative traits (Supplementary Table S2) with considerable ranges in plant height $(277.67-442.50 \mathrm{~cm})$, leaf number $(7.67-14.0)$, internode number (7.67-13.0), green-leaf weight (5.97-80.75 g), cane yield (16.65-124.80 t/ha), juice yield (2.67-52.20 kl/ha), bagasse yield (12.74-49.80 t/ha), sugar concentration in ${ }^{\circ}$ Brix (6.90-15.16), estimated sugar yield (0.19-5.43 $\left.\mathrm{t} / \mathrm{ha}\right)$, and estimated ethanol yield $(0.67-4.99 \mathrm{kl} / \mathrm{ha})$ (Table 2).

The coefficient of variation was between low and moderate, ranging from $3.56 \%$ to $15.84 \%$. The range of parameters was considerable. For instance, the sorghum hybrid Ganymed produced the highest green leaf weight $(80.75 \mathrm{~g})$, cane yield $(124.80 \mathrm{t} / \mathrm{ha})$, juice yield $(52.20 \mathrm{kl} / \mathrm{ha})$, bagasse yield $(49.80 \mathrm{t} / \mathrm{ha})$, and predicted ethanol yield $(4.99 \mathrm{kl} / \mathrm{ha})$. In contrast, the grain variety Ruzrok produced the lowest plant height $(277.67 \mathrm{~cm})$, leaf number (7.67), internode number (7.67), green leaf weight (5.97 g), cane yield (16.65 t/ha), juice yield $(2.67 \mathrm{kl} / \mathrm{ha})$, bagasse yield $(12.74 \mathrm{t} / \mathrm{ha})$, and predicted sugar $(0.19 \mathrm{t} / \mathrm{ha})$ and ethanol $(0.67 \mathrm{kl} / \mathrm{ha})$ yields compared to the other genotypes (Table 2). While the sweet genotype KIT1 produced a significantly higher sugar concentration $\left(15.16^{\circ}\right.$ Brix $)$, the grain landrace Razinieh showed the lowest sugar concentration (6.90 ${ }^{\circ}$ Brix). However, all the hybrids registered sugar concentration higher than 10 , except Sole $\left(9.70^{\circ}\right.$ Brix $)$, while grain sorghum genotypes recorded sugar concentration less than 9 . 
Table 2. Mean values of agro-morphological traits recorded from 14 sweet, grain, and dual-purpose sorghum genotypes, their grouped overall mean values, least significant difference, and coefficient of variation as percentage (C.V\%) at dough stage under temperate climatic conditions.

\begin{tabular}{|c|c|c|c|c|c|c|c|c|c|c|}
\hline Cultivar & $\begin{array}{c}\text { Plant } \\
\text { Height } \\
\text { (cm) }\end{array}$ & $\begin{array}{c}\text { Leaf } \\
\text { Number }\end{array}$ & $\begin{array}{l}\text { Internode } \\
\text { Number }\end{array}$ & $\begin{array}{c}\text { Leaf } \\
\text { Weight } \\
\text { (g/Plant) }\end{array}$ & $\begin{array}{l}\text { Cane } \\
\text { Yield } \\
\text { (t/ha) }\end{array}$ & $\begin{array}{l}\text { Juice } \\
\text { Yield } \\
\text { (kl/ha) }\end{array}$ & $\begin{array}{c}\text { Bagasse } \\
\text { yield } \\
\text { (t/ha) }\end{array}$ & $\begin{array}{l}\text { Sugar } \\
\text { Content } \\
\left({ }^{\circ} \text { Brix) }\right.\end{array}$ & $\begin{array}{l}\text { Sugar } \\
\text { Yield } \\
\text { (t/ha) }\end{array}$ & $\begin{array}{c}\text { Ethanol } \\
\text { Yield } \\
\text { (kl/ha) }\end{array}$ \\
\hline Zerberus & 361.66 & 12.00 & 12.00 & 46.87 & 93.87 & 41.87 & 33.53 & 11.27 & 4.20 & 3.77 \\
\hline Juno & 382.50 & 13.00 & 13.00 & 44.30 & 82.80 & 35.00 & 38.20 & 12.80 & 3.97 & 3.31 \\
\hline Bulldozer & 315.50 & 14.00 & 12.00 & 65.00 & 93.70 & 38.50 & 33.80 & 11.80 & 4.03 & 3.75 \\
\hline Ganymed & 426.50 & 14.00 & 12.00 & 80.75 & 124.80 & 52.20 & 49.80 & 11.10 & 5.14 & 4.99 \\
\hline Phoenix & 305.50 & 10.00 & 10.00 & 39.40 & 54.50 & 21.80 & 26.30 & 13.60 & 2.63 & 2.18 \\
\hline Hannibal & 397.50 & 12.00 & 12.00 & 54.40 & 106.50 & 46.10 & 47.60 & 13.30 & 5.43 & 4.26 \\
\hline Freya & 415.00 & 10.00 & 11.00 & 25.85 & 55.10 & 18.20 & 29.00 & 12.70 & 2.05 & 2.20 \\
\hline Merlin & 403.00 & 11.00 & 11.00 & 36.65 & 84.20 & 41.40 & 35.20 & 13.70 & 5.02 & 3.37 \\
\hline Tarzan & 442.50 & 11.00 & 12.00 & 47.50 & 109.40 & 38.70 & 45.80 & 13.60 & 4.66 & 4.38 \\
\hline Sole & 396.00 & 10.00 & 10.00 & 15.05 & 38.11 & 9.10 & 21.50 & 9.70 & 0.78 & 1.52 \\
\hline Razinieh & 284.00 & 10.00 & 10.00 & 30.50 & 42.39 & 11.46 & 18.95 & 6.90 & 0.71 & 1.69 \\
\hline Ruzrok & 277.67 & 7.67 & 7.67 & 5.97 & 16.65 & 2.67 & 12.74 & 8.10 & 0.19 & 0.67 \\
\hline So-29 & 308.50 & 11.00 & 11.00 & 24.50 & 76.00 & 35.30 & 32.00 & 12.70 & 3.97 & 3.04 \\
\hline KIT1 & 284.00 & 9.33 & 9.33 & 63.43 & 78.57 & 35.40 & 23.45 & 15.16 & 4.75 & 3.14 \\
\hline Overall mean & 357.13 & 11.07 & 10.92 & 41.44 & 75.47 & 30.55 & 31.99 & 11.88 & 3.39 & 3.01 \\
\hline F-test & $* * * *$ & $* * * *$ & $* * * *$ & $* * * *$ & $* * * *$ & $* * * *$ & $* * * *$ & $* * * *$ & $* * * *$ & $* * * *$ \\
\hline LSD (0.05) & 12.25 & 0.36 & 0.36 & 4.02 & 4.87 & 1.82 & 2.57 & 0.56 & 0.32 & 0.19 \\
\hline C.V $(\%)$ & 9.06 & 3.78 & 3.56 & 13.78 & 15.84 & 11.55 & 9.79 & 6.82 & 8.62 & 11.85 \\
\hline
\end{tabular}

Data were analyzed by F-test. LSD: least significant differences within the trait for all the varieties $(p<0.05) .{ }^{* * * *}$ Significant at 0.0001 probability level.

\subsection{Phenotypic Correlation Coefficients and Path Analysis}

The results of correlations analysis carried out among the 10 quantitative traits are given in Table 3. Sugar concentration (in ${ }^{\circ}$ Brix) showed significant positive correlations with number of internode $\left(r=0.37^{*}\right)$, leaf weight $\left(r=0.44^{* *}\right)$, cane yield $\left(r=0.54^{* * *}\right)$, juice yield $\left(r=0.60^{* * *}\right)$, and Bagasse yield $\left(r=0.49^{* * *}\right)$. However, sugar concentration did not correlate with plant height $\left(r=0.28^{\mathrm{ns}}\right)$, nor with leaf number $\left(r=0.21^{\mathrm{ns}}\right)$. Sugar yield was also significantly and positively correlated with plant height $\left(r=0.40^{* *}\right)$, leaf number $\left(r=0.64^{* * * *}\right)$, internode number $\left(r=0.66^{* * * *}\right)$, leaf weight $\left(r=0.77^{* * * *}\right)$, cane yield $\left(r=0.92^{* * * *}\right)$, juice yield $\left(r=0.97^{* * * *}\right)$, and bagasse yield $\left(r=0.82^{* * * *}\right)$.

The direct and indirect effects of plant height, leaf number, internode number, leaf weight, cane yield, juice yield, bagasse yield, and sugar concentration (in ${ }^{\circ}$ Brix) on sugar yield were estimated by path analysis. They are presented in Table 4 . The path coefficient analysis based on sugar yield as a dependent variable was consistent with a model where juice yield (0.894), ${ }^{\circ}$ Brix (0.211), bagasse yield (0.062), cane yield (0.011), and internode number (0.002) exhibited positive direct effects, while plant height $(-0.039)$, leaf number $(-0.123)$, and leaf weight $(-0.005)$ showed negative direct effects on sugar yield. Highly positive indirect effects on sugar yield were exerted by juice yield via plant height $(0.386)$, leaf number (0.681), internode number (0.662), leaf weight (0.732), cane yield (0.864), bagasse yield (0.777), and sugar content as ${ }^{\circ}$ Brix (0.544). In contrast, leaf weight contributed negatively and very little on sugar yield via all the studied traits. Internode number had positive and very low indirect effect on sugar yield. Bagasse yield and ${ }^{\circ}$ Brix had moderate indirect effect on sugar yield via other traits under study. 
Table 3. Phenotypic correlation coefficient of different agro-morphological traits obtained from 14 sorghum genotypes.

\begin{tabular}{|c|c|c|c|c|c|c|c|c|}
\hline Traits & $\begin{array}{c}\text { Leaf } \\
\text { Number }\end{array}$ & $\begin{array}{l}\text { Internode } \\
\text { Number }\end{array}$ & Leaf Weight & Cane Yield & Juice Yield & $\begin{array}{c}\text { Bagasse } \\
\text { Yield }\end{array}$ & ${ }^{\circ}$ Brix & Sugar Yield \\
\hline Plant height & $0.43^{* *}$ & $0.62 * * * *$ & $0.23 \mathrm{~ns}$ & $0.54^{* * *}$ & $0.43 * *$ & $0.71^{* * *}$ & $0.28 \mathrm{~ns}$ & 0.40 ** \\
\hline Leaf number & 1.00 & $0.88^{* * * *}$ & $0.72 * * * *$ & $0.79 * * * *$ & $0.76^{* * * *}$ & $0.76^{* * * *}$ & $0.21 \mathrm{~ns}$ & $0.64^{* * * *}$ \\
\hline Internode number & & 1.00 & $0.56^{* * * *}$ & $0.79^{* * * *}$ & $0.74^{* * * *}$ & $0.83^{* * * *}$ & $0.37^{*}$ & $0.66^{* * * *}$ \\
\hline Leaf weight & & & 1.00 & $0.84^{* * * *}$ & $0.81^{* * * *}$ & $0.68^{* * * *}$ & $0.44^{* *}$ & $0.77^{* * * *}$ \\
\hline Cane yield & & & & 1.00 & $0.96^{* * * *}$ & $0.92 * * * *$ & $0.54 * * *$ & $0.92^{* * * *}$ \\
\hline Juice yield & & & & & 1.00 & $0.86^{* * * *}$ & $0.60^{* * *}$ & $0.97 * * * *$ \\
\hline Bagasse yield & & & & & & 1.00 & $0.49 * * *$ & $0.82 * * * *$ \\
\hline${ }^{\circ}$ Brix & & & & & & & 1.00 & $0.75^{* * * *}$ \\
\hline
\end{tabular}

ns $=$ non-significant; ${ }^{*}, * * * * *$ and ${ }^{* * * *}$ Significant at $0.05,0.01,0.001$, and 0.0001 probability levels, respectively.

Table 4. Direct (bold diagonal) and indirect effect (off diagonal) of different quantitative characters on sugar yield of sorghum.

\begin{tabular}{|c|c|c|c|c|c|c|c|c|c|}
\hline Characters & $\begin{array}{c}\text { Plant } \\
\text { Height }\end{array}$ & $\begin{array}{c}\text { Leaf } \\
\text { Number }\end{array}$ & $\begin{array}{l}\text { Internode } \\
\text { Number }\end{array}$ & $\begin{array}{c}\text { Leaf } \\
\text { Weight }\end{array}$ & Cane Yield & Juice Yield & $\begin{array}{c}\text { Bagasse } \\
\text { Yield }\end{array}$ & ${ }^{\circ}$ Brix & $\begin{array}{l}\text { Sugar } \\
\text { Yield }\end{array}$ \\
\hline Plant height & -0.039 & -0.053 & 0.001 & -0.001 & 0.006 & 0.386 & 0.044 & 0.061 & $0.405^{* *}$ \\
\hline Leaf number & -0.017 & -0.123 & 0.001 & -0.003 & 0.008 & 0.681 & 0.047 & 0.046 & $0.640 * * * *$ \\
\hline Internode number & -0.025 & -0.109 & 0.002 & -0.003 & 0.009 & 0.662 & 0.052 & 0.079 & $0.666^{* * * *}$ \\
\hline Leaf weight & -0.009 & -0.089 & 0.001 & -0.005 & 0.010 & 0.732 & 0.042 & 0.095 & $0.776^{* * * *}$ \\
\hline Cane yield & -0.021 & -0.098 & 0.001 & -0.004 & 0.011 & 0.864 & 0.057 & 0.115 & $0.925^{* * * *}$ \\
\hline Juice yield & -0.017 & -0.094 & 0.001 & -0.004 & 0.011 & 0.894 & 0.053 & 0.128 & $0.972^{* * * *}$ \\
\hline Bagasse yield & -0.028 & -0.095 & 0.001 & -0.004 & 0.010 & 0.777 & 0.062 & 0.104 & $0.828^{* * * *}$ \\
\hline${ }^{\circ}$ Brix & -0.011 & -0.027 & 0.001 & -0.002 & 0.006 & 0.544 & 0.031 & 0.211 & $0.752^{* * * *}$ \\
\hline
\end{tabular}

Residual effect $=0.0899 .{ }^{* *}$ and ${ }^{* * * *}$ Significant at 0.01 and 0.0001 probability levels, respectively.

\subsection{Sugar Accumulation Across Internodes of the Stem}

For each internode individually (from base to top), sugar concentration (in ${ }^{\circ}$ Brix), internode weight, internode bagasse weight, internode juice volume, and internode length were analyzed for all the 14 genotypes (Figure 1). Similar patterns were observed between all the genotypes in sugar accumulation across the stem. The central internodes accumulated higher sugar concentration, especially from the fourth to the seventh internode (Figure 1A), while the basal internodes accumulated more weight, especially from the second to the fourth or fifth internode (Figure 1B). This heavier weight for basal internodes was correlated with a higher juice content (Figure 1C). As a result, the central internodes although storing less juice, nevertheless produced the highest sugar concentration (measured as ${ }^{\circ}$ Brix). In KIT1 and So-29 (sweet types), and in Buldozer, Hannibal, and Merlin (dual-purpose types), sugar concentration was significantly higher compared to the other genotypes studied (Figure 1A). Hannibal, Ganymed, and So-29 displayed heavier internode weight and higher juice volume for basal internodes, which increased significantly after the internode number 3, while the sweet genotype KIT1 had a stable internode weight and juice volume up to the internode number 8 (Figure 1B,C).

Sugar concentration (in ${ }^{\circ}$ Brix) showed a positive and significant correlation with internode weight $(r=0.34, p<0.0001)$, internode juice volume $(r=0.35, p<0.0001)$, and internode bagasse weight $(r=0.25, p<0.01)$ (Figure 2A-C). No significant relation was observed between sugar content (in ${ }^{\circ}$ Brix) and internode length $(r=-0.03, p<0.06)$ (Figure 2D). The internode juice volume exhibited a significant positive correlation with internode weight $(r=0.91, p<0.0001)$, but no significant correlation with internode length $(r=-0.15, p<0.06)$ (Figure 2E,F, respectively). 

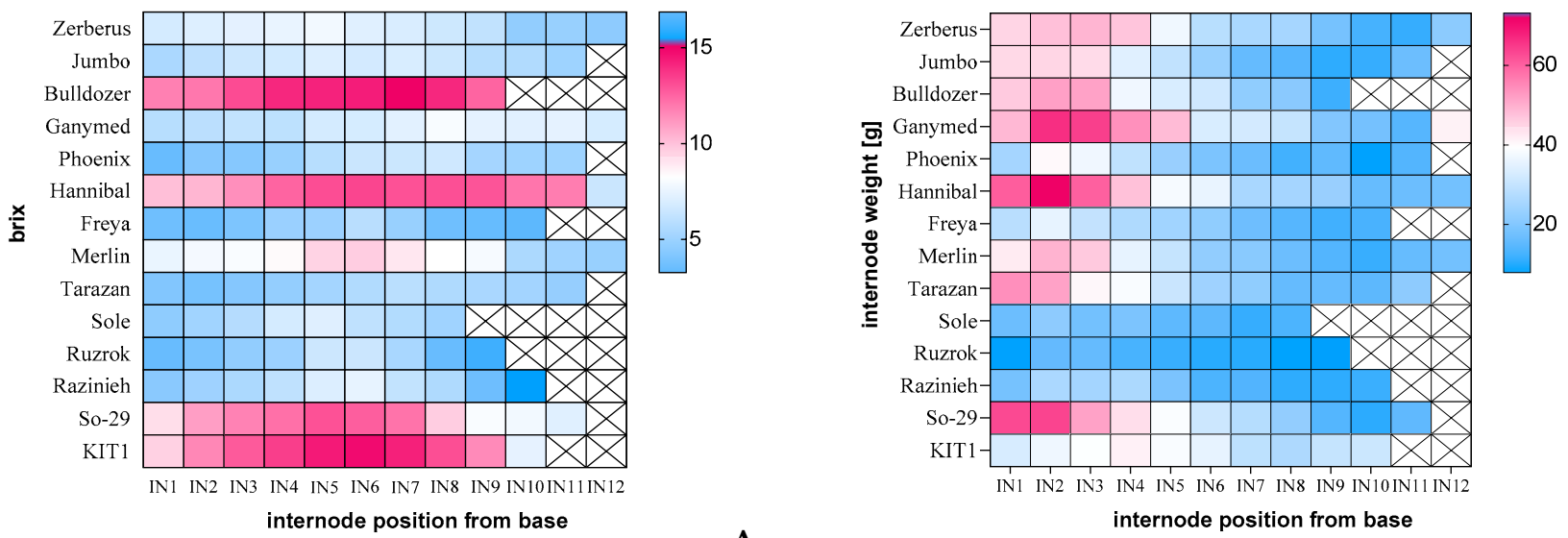

A
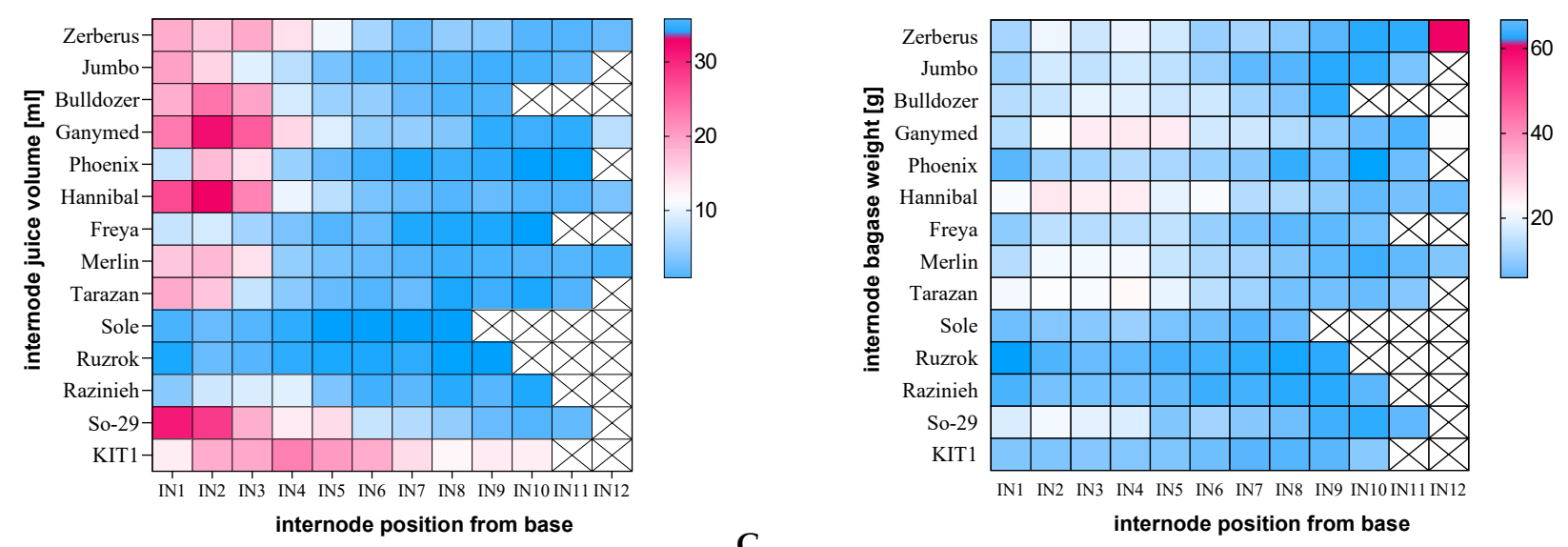

C

D

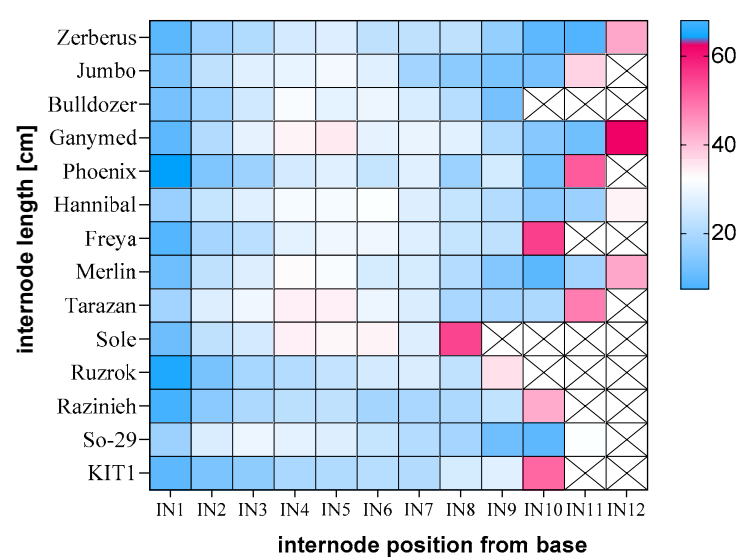

E

Figure 1. Differences in stem biomass and sugar-related parameters in the individual internodes of 14 sorghum genotypes grown in 2018 season in South-West Germany: (A) sugar concentration as ${ }^{\circ}$ Brix, (B) internode weight, (C) internode juice volume, (D) internode bagasse weight, and (E) internodes length. Values are means of three replicates (5 samples in each replicate). Boxes with $x$ indicate the absence of the internode. The blue color represents the trend of decrease and the purple color represents a rising trend. Heat map was generated using GraphPad Prism 8.4.3 software. 
A

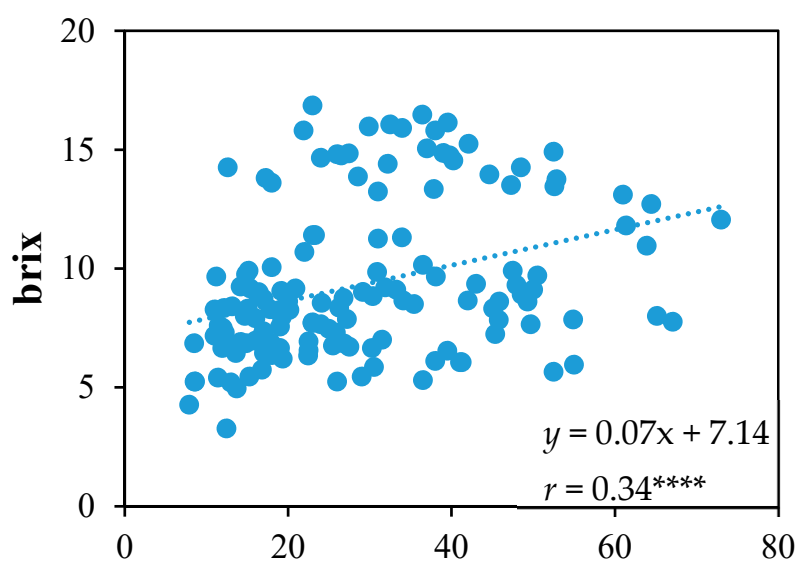

C

internode weight $[\mathrm{g}]$
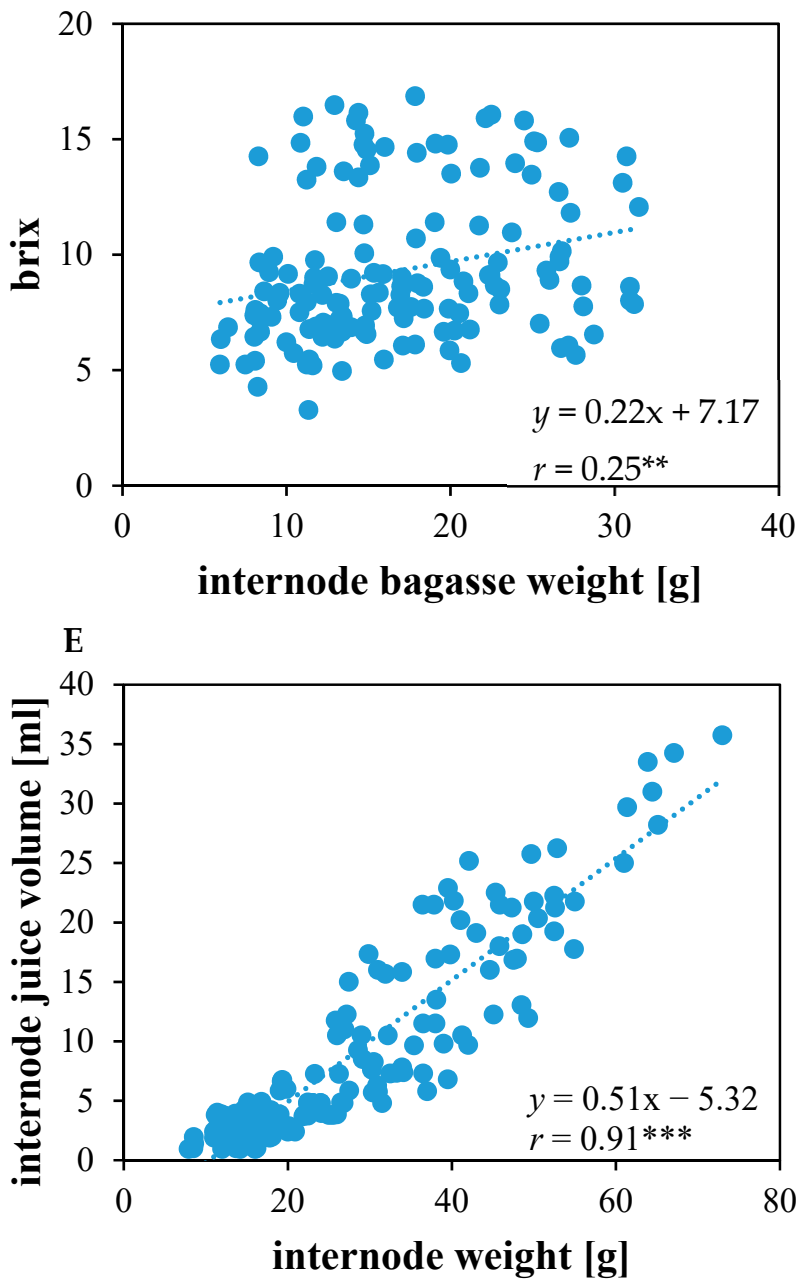
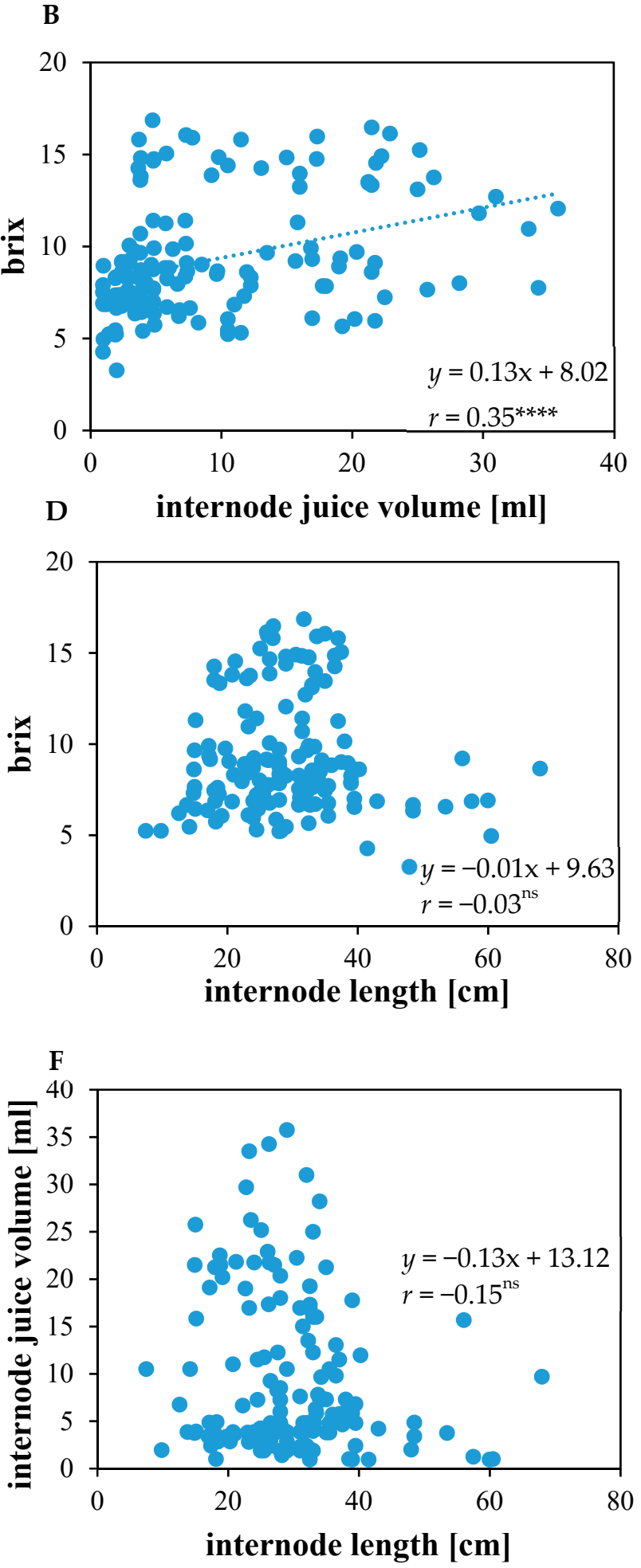

Figure 2. Relationship between sugar-related stem parameters of 14 sorghum genotypes grown in 2018 season in South-West Germany: (A) ${ }^{\circ}$ Brix over weight in individual internodes, (B) ${ }^{\circ}$ Brix over juice volume in individual internodes, (C) ${ }^{\circ}$ Brix over bagasse weight in individual internodes, (D) ${ }^{\circ}$ Brix over length in individual internodes, (E) juice volume over weight in individual internodes, and (F) juice volume over length in individual internodes. ns = non-significant; ${ }^{*}, * * * *$, and **** Significant at $0.05,0.01,0.001$, and 0.0001 probability levels, respectively. 


\subsection{Diversity Analysis of Agro-Morphological Traits}

Data recorded on 8 quantitative traits were used for clustering by the Average linkage method after the data had been standardized. In the resulting dendrogram, the investigated sorghum genotypes are separated into two main clusters (Figure 3A). Cluster I comprises two grain sorghum genotypes (Razinieh and Ruzrok), which recorded low in sugar content, plant height, internode number, cane yield, juice yield, bagasse yield, sugar yield, and ethanol yield. Cluster II is composed of all hybrids and sweet sorghum genotypes. Additionally, cluster II can be subdivided into two groups. Although group A contains seven hybrids (Zerberus, Juno, Bulldozer, Hannibal, Tarzan, Merlin, and Ganymed), with generally higher plant height, leaf number, internode number, fresh leaf weight, cane yield, bagasse yield, and sugar yield, group B contains two sweet genotypes (KIT1 and So-29) and three dual-purpose hybrids (Phoenix, Freya, and Sole). Group B is defined by its superior sugar concentration (in ${ }^{\circ}$ Brix) with exception of the hybrid Sole.

A

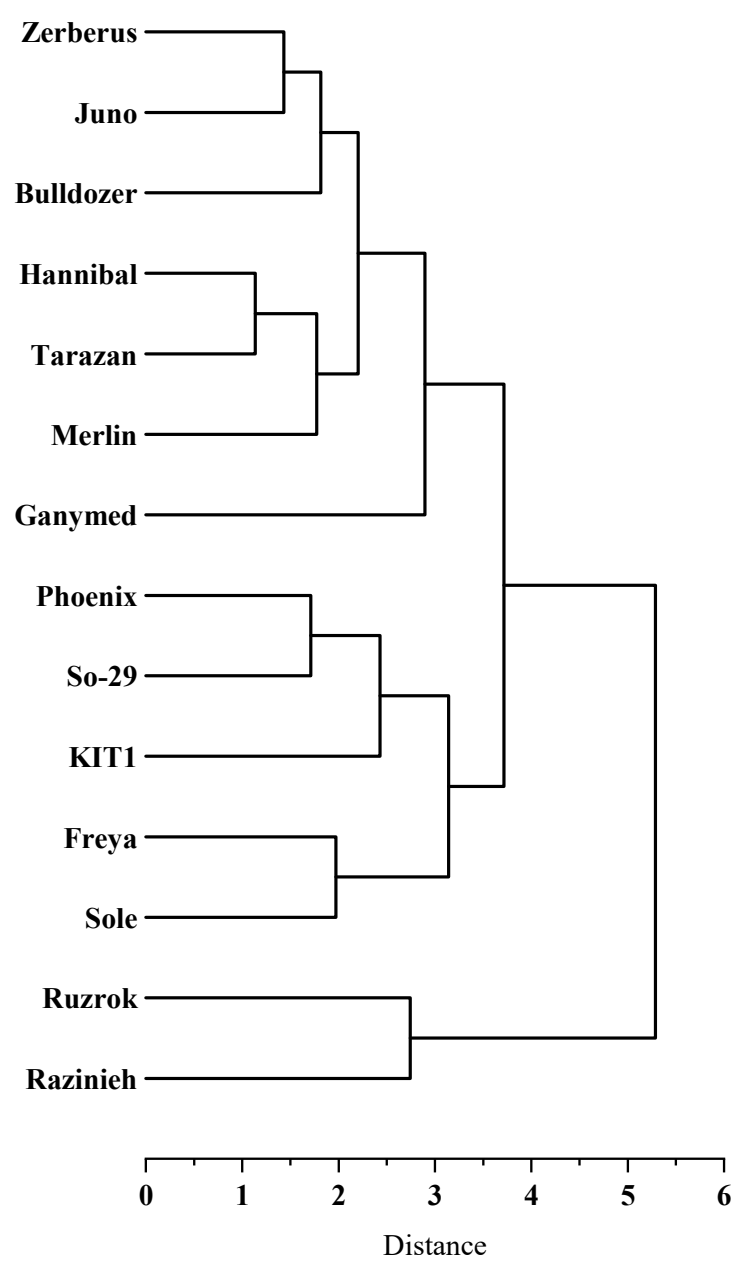

B

\begin{tabular}{lll}
\hline Traits & PC1 & PC2 \\
\hline Plant height & 0.26 & -0.62 \\
Leaf number & 0.33 & -0.14 \\
Internode number & 0.37 & -0.29 \\
Leaf weight & 0.34 & 0.39 \\
Cane yield & 0.40 & 0.10 \\
Juice yield & 0.39 & 0.23 \\
Bagasse yield & 0.40 & 0.16 \\
${ }^{\circ}$ Brix & 0.23 & 0.50 \\
\hline Eigenvalue & 5.66 & 1.06 \\
Total variance (\%) & 70.78 & 12.43 \\
Cumulative variance (\%) & 70.78 & 83.21 \\
\hline
\end{tabular}

$\mathrm{C}$

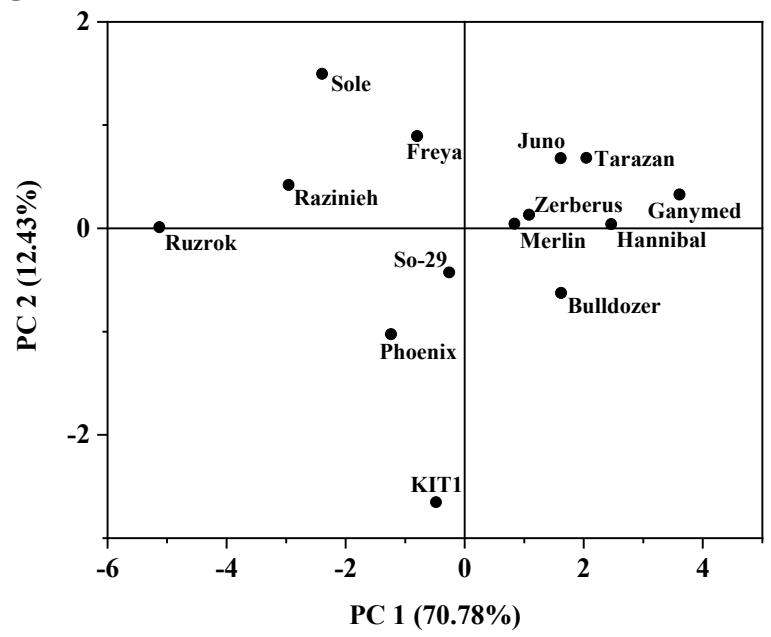

Figure 3. Clustering and principal component analysis based on 8 agro-morphological and sugar-related traits in 14 sorghum genotypes. (A) Dendrogram based on Euclidean distance and Average linkage method. (B) Eigenvectors, total variation, eigenvalue, and cumulative variance. (C) PCA plot showing scores for PC1 and PC2.

PCA results show that $83.21 \%$ of total variation among genotypes is contained within the first two principal components, having an eigenvalue (1.06) greater than one (Figure 3B). The score plot of 14 genotypes based on the first two principal components is presented in 
Figure 3C. The first principal component is strongly correlated with four of the original variables. The first principal component increases with increasing cane yield, bagasse yield, juice yield, and internode number and explains $71 \%$ of the variation. The second principal component increases with only two of the values, decreasing plant height and increasing sugar concentration (in ${ }^{\circ}$ Brix), and contributes only with $12 \%$ of the variation.

\section{Discussion}

Biofuels are a sustainable and renewable energy source deriving from biomass as organic matter [35]. As suggested by several studies, plants grown for the purpose of biofuel production have the potential to reduce net greenhouse gas emissions [36]. About $2.5 \%$ of the world's transportation fuels are currently produced from crop plants like sweet sorghum [37]. The multiple-purpose crop sorghum is used for food and fodder, as well as for bioethanol production due to its easily fermentable sugar $[37,38]$. The current study provides details of major differences between sweet, grain, and dual-purpose sorghums in terms of stem-sugar accumulation.

\subsection{More Cane and Sugar Yields in Dual-Purpose Hybrid Sorghum but Higher Sugar Content in Sweet Sorghum}

In the present investigation, morphological and sugar-related traits like plant height, leaf and internode numbers, leaf weight, cane yield, juice yield, bagasse yield, sugar concentration (as ${ }^{\circ}$ Brix), as well as predicted ethanol yield significantly differed among the 14 tested sorghum genotypes (Table 2). Genotypic differences with respect to morphological characters and ethanol production have also been reported by previous studies [19,39-42]. In the set of the current work, the hybrid sorghum Ganymed, Tarzan, Hannibal, Zerberus, Bulldozer, and Merlin produced the highest cane yield, juice yield and bagasse yield compared with the two sweet genotypes, KIT1 and So-29, and the two grain sorghum landraces, Razinieh and Ruzrok. These six hybrids are expected to produce the highest ethanol yield, which depends on cane yield and juice yield [43,44].

Due to the wide variability in juice yield and extractability between sweet and grain sorghum genotypes, an assessment of genotypes for potential ethanol and sugar yields is of great importance $[9,10,13,16,23,27]$. By comparison of the total average of grain and sweet sorghum genotypes with dual-purpose hybrids, phenotypic differences exhibiting a taller, sugar-rich juicy stem, and a higher fresh biomass production were observed in hybrid plants (Table 2). Because of their frequently tall habitus, hybrid sorghum accumulated large biomass. For a range of morphological and agronomical traits, similar variation has been reported, indicating the prospect of an improvement of crops as biofuel feedstock sources $[31,39,45]$. Even though grain and sweet sorghum are highly similar with respect to structural genes, in regulatory genes as well as in sugar metabolism genes potential deletions and loss-of-function mutations were identified, that are likely crucial for the accumulation of stem sugar [25]. Regarding these discrepancies, further factors affecting physiology, morphology and molecular characteristics are needed to be included to understand the difference between sorghum types in their stem storage capacity.

The sweet sorghum KIT1 was superior to other evaluated genotypes in terms of sugar concentration (measured as ${ }^{\circ}$ Brix). However, the superiority of dual-purpose hybrids, Hannibal, Ganymed, and Merlin in juice yield compared to KIT1 consequently leads to a higher potential of sugar and ethanol yield than that of KIT1 (Table 2). Although sorghum is naturally self-pollinating, heterosis is well-described for grain yield and biomass production [46]. With the discovery of cytoplasmic male sterility in the 1950s, the commercial production of grain sorghum was completely replaced by hybrids [47]. At present, a significant proportion of grain, biomass, and forage production is based on hybrids in Germany [48]. To enhance the value of this crop for ethanol production, the same genetic mechanism can be utilized to improve the concentration of soluble sugars in grain sorghum varieties. As already described by [49], the reduction and fluctuations of the photoperiod were observed to negatively affect the quantity and quality of stem and juice yields in KIT1. The parents of KIT1 originated from South India, which are adopted to semi-arid 
environmental conditions. However, all the hybrids were developed by the company KWS in Germany, and they are suitable to grow in the temperate environmental conditions.

The grain sorghum genotypes Ruzrok and Razinieh were bred and improved from landraces. Ruzrok recorded the lowest values for all the studies parameters compared with other genotypes. The Syrian landrace Razinieh showed better performance than Ruzrok with respect to growth, biomass yield, sugar yield, and ethanol productivity under temperate environmental condition. This genotype has been cultivated in Syria for a long time to alleviate fodder and food shortages during dry seasons. Later, its grain yield was improved by a bulk breeding program under respect to maintain its drought tolerance capability $[19,50]$.

\subsection{Higher Cane and Juice Yields and More Sugar Accumulation in the Stem}

To predict the consequences of selections for one trait on the performance of others, the examination of genetic relationships between different traits is of great importance. The statistically determined relationships visualized in a correlation matrix showed interesting positive correlations between sugar concentration (as ${ }^{\circ}$ Brix) and internode number, leaf weight, cane yield, juice yield, Bagasse yield, and sugar yield (Table 3). Sugar concentration (as ${ }^{\circ}$ Brix) was positively correlated with plant height, but not significantly. Prior research activities had identified a positive correlation between sugar concentration and plant height in sweet sorghum genotypes [51]. The observed positive relation of sugar concentration (as ${ }^{\circ}$ Brix) and leaf weight may be a desirable trait for further sorghum breeding activities, since plants need leaf areas to synthesize carbohydrates through photosynthesis. For higher yields of biomass and storage of energy in its stalk through the growth period, plants need more photosynthetic active areas in form of leaf $[23,52,53]$. The positive relations between internode numbers and cane yield suggest that taller plants were accumulating more biomass in the stalk $[19,54]$. This study showed that plant height, leaf number, leaf weight, cane yield, and juice yield positively affected the sugar yield in fresh stalk. Similar results were obtained by $[19,51,54]$. Furthermore, the accumulation of stem sucrose was correlated with stem growth during anthesis [55].

Partitioning sugar-related traits and other morphological parameters into direct and indirect effects is of importance for breeding so that traits that directly contribute to sugar yield are selected. The results show that juice yield and concentration of soluble sugars (as ${ }^{\circ}$ Brix) had significant direct and indirect effects on sugar yield (Table 4). The remaining traits had low negative indirect effect on sugar yield. Therefore, sugar yield can be improved by selecting for high juice volume and ${ }^{\circ}$ Brix. Genotypes developing a juicy stem and high sugar concentrations ( ${ }^{\circ}$ Brix values) were described to lead to high sugar and ethanol yield $[17,43]$. Cane and juice yield in sorghum are mainly determined by stem properties that concern the capacity to act as a sink for soluble sugars [56]. In dual-purpose hybrids and the sweet KIT1 genotype, ${ }^{\circ}$ Brix, fresh weight of internodes, juice content per internode, and leaf weight were significantly higher than in Razinieh and Ruzrok landraces. This result is consistent with previous observations, where sweet sorghum was shown to produce more weight and to exhibit higher sugar concentration reflected as higher refraction (in ${ }^{\circ}$ Brix) compared with grain sorghum varieties [11,13,15,27,39,52,53,57]. Comparative studies between sorghum hybrids and open-pollinated sorghum varieties (OPV) described that hybrid sorghum produced higher yields in fresh biomass, juice, and sugar compared to OPV [46]. Because of the higher activity of photosynthesis and starch metabolism genes during daytime, hybrid plants of corn or sorghum tend to grow better and bigger than their stable varieties [58].

\subsection{Internode Weight Rather Than Length Can Be Used as Predictor for Sugar Yield}

In sorghum yields of cane and juice are mainly determined by those properties that concern the stem capacity to act as sink tissue for soluble sugars. All tested genotypes exhibited higher values for sugar concentration in terms of ${ }^{\circ}$ Brix in the central internodes (Figure 1A), while accumulating more weight and juice volume in the basal internodes 
(Figure 1B,C). Thus, the central internodes although storing comparatively less juice, nevertheless produced the highest sugar concentration (Figure 1C). This result is consistent with earlier observations showing that it was the central internodes in sorghum stems that displayed the highest ${ }^{\circ}$ Brix $[27,51,59]$. The sweet sorghum cultivars Della and Rio showed similarities in the internode sugar concentration dynamics, whereas in both genotypes, the total sugar concentration was remarkably increased after anthesis and the upper and lower internodes had lower sugar concentrations compared to the middle internodes [60].

In KIT1, Bulldozer, Hannibal, Merlin, and So-29, the sugar concentration was significantly higher compared to other tested genotypes (Figure 1A). Thus, the superiority of these genotypes over other hybrids and landraces on the level of the entire stem is due to its heavier, juicier, and more sugary internodes. This result is consistent with previous observations, where sweet sorghum was shown to produce more weight and to exhibit higher sugar concentration compared to grain sorghum varieties [11,13,15,27,39,57,61-63]. A common feature of sweet sorghum cultivars observed in Keller, NK 405, and Tracy, was the significantly lower sucrose contents (in ${ }^{\circ}$ Brix) in the upper and lower three internodes during anthesis [59]. In the last top internodes and peduncle of the landrace IS2848, lower sucrose concentrations were observed [64]. Hence, these data suggest that KIT1, So-29, Bulldozer, Merlin, and Hannibal accumulate higher stem solutes than landraces and other hybrids through a combination of increased internode number, higher juice volume per internode, and a greater sugar content per internode that occurs because of significant increases in sugar content during post-flowering stage.

Sugar concentration (in ${ }^{\circ}$ Brix) showed non-significant but positive correlation with plant height (Table 3) and negative correlation with internode length (Figure 2D). However, especially when the correlation coefficients are low, there will likely be genotypes that do combine taller internode with high sugar concentration in the stem. In the case of dualpurpose hybrids, these genotypes tend to be taller and to contain a moderate concentration of soluble sugars in their stems compared to sweet genotypes, while grain landraces tend to be shorter and accumulate less sugar in the stem (Table 2; Figure 1A,E). [51] reported a weak relation between plant height and sugar concentration. However, there are several reports that describe a positive correlation between plant height and sugar accumulation in sorghum $[13,23,61,62,65,66]$, suggesting that sugar accumulation in the stem may depend on increased plant height.

\subsection{Sweet Sorghums Are More Closer to Dual-Purpose Hybrids Than Grain Landraces}

As to assess genetic diversity, phenotypic traits are commonly used as simple indicators to quantify genetic variations that are of interest for plant breeding programs $[67,68]$. Trait clustering analysis revealed that the two grain landraces Razinieh and Ruzrok were clustered together far from 12 other dual-purpose hybrids and sweet sorghums (Figure 3A). These landraces were recorded low in sugar concentration $\left({ }^{\circ}\right.$ Brix $)$, plant height, internode number, cane yield, juice yield, bagasse yield, sugar yield, and ethanol yield compared with other genotypes (Table 2). All examined sweet and hybrid sorghums were grouped in one cluster. In general, the genotypes of this cluster were taller and had more leaf and internode numbers, higher cane yield, fresh leaf weight, and bagasse yield (Table 2). The broad trait diversity among and between sweet, grain, and dual-purpose sorghum genotypes provides ample opportunities for genotype enhancement through breeding programs. To select parents for crossing, grouping of accessions with agro-morphological and, most likely, genetic similarities may help [69]. Large morphological variations were found among different Indian sweet and grain sorghums [70]. While sweet sorghums are selected and optimized for increased size and thickness of their stem, grain sorghums are mainly bred to optimize grain yield, and dual-purpose hybrids are developed for high shoot biomass and grain yield by heterosis effects [71]. The variation in the magnitude of heterosis between the hybrids in sub-cluster one and two (Figure 3A) likely reflects the increased genetic distance between the parental lines of these hybrids in relation to adaptation to temperate environmental conditions. In addition, compared to the grain 
landraces and sweet sorghums, all the hybrids (except Sole) showed superiority in their adaptation to the temperate environmental conditions, indicating the potential of using these hybrids as a source for biofuel production in Germany.

To find traits that contribute most to the total amount of variation in large data sets and to assess the magnitude of variation, PCA analyses proved a valuable tool [6]. PCA results show that $83.21 \%$ of total variation among genotypes is contained within the first two principal components (Figure 3B,C). With only four traits (cane yield, bagasse yield, juice yield, and internode number) explaining most of the variation, strong correlations between agro-morphological traits are evident. To achieve better separation of different genotypes, other traits need to be considered.

\section{Conclusions}

Ten dual-purpose hybrids (grain and biomass), two sweet genotypes, and two grain landraces of sorghum were phenotypically characterized to determine their potential for use as source of bioethanol production under temperate environmental conditions. Dualpurpose hybrids Ganymed, Hannibal, Tarzan, Merlin, and Zerberus showed internodes that were significantly heavier, were richer in sugar and juice, had taller height, and had higher sugar and ethanol potential yields compared with sweet and grain genotypes, indicating the potential of these five hybrids as a source for bioethanol production in Germany. All genotypes showed similar pattern of sugar and juice accumulation in the stem, where more sugar was accumulated in the central internodes and more weight and juice volume were found in the basal internodes. Significant and positive interrelationships were recorded between sugar-related parameters. Individual internode weight rather than internode length can be used as predictor for sugar yield in our sorghum materials. Phenotypic clustering analysis showed that sweet sorghums are closer to dual-purpose hybrids than to grain landraces. Further research is needed to estimate the genetic diversity among the genotypes at molecular level.

Supplementary Materials: The following are available online at https:/ /www.mdpi.com/article/10 $.3390 / \mathrm{d} 13050192 / \mathrm{s} 1$, Table S1: Temperature and rainfall measured in Karlsruhe during the summer season 2018, Table S2: Analysis of variance of 10 agro-morphological traits recorded from 14 sweet, grain, and dual-purpose sorghum genotypes.

Author Contributions: Conceptualization, A.K., methodology, validation, and investigation, A.K.; resources, A.K. and P.N.; formal analysis, A.K., N.F., J.H., K.K. and T.H.; writing-original draft preparation, A.K., writing-review and editing, T.H. and P.N. All authors have read and agreed to the published version of the manuscript.

Funding: This research did not receive any specific grant from funding agencies in the public.

Institutional Review Board Statement: Not applicable.

Informed Consent Statement: Not applicable.

Data Availability Statement: The data presented in this study are available on request from the corresponding author due to the KIT1 variety being under registration.

Acknowledgments: The International Institute for Education (USA) and the Philipp Schwartz Initiative of the Alexander von Humboldt Foundation (Germany) scholarships to the corresponding author are greatly acknowledged. We thank Joachim Daumann, Anna-Luise Kuppinger, and Dutsareeya Kusterer for competent cultivation and maintenance of the plant material used in this study. We acknowledge support by the KIT-Publication Fund of the Karlsruhe Institute of Technology.

Conflicts of Interest: The authors declare no conflict of interest.

\section{References}

1. Keairns, D.L.; Darton, R.C.; Irabien, A. The Energy-Water-Food Nexus. Annu. Rev. Chem. Biomol. Eng. 2016, 7, 239-262. [CrossRef]

2. Blätke, M.-A.; Bräutigam, A. Evolution of $C_{4}$ photosynthesis predicted by constraint-based modelling. Elife 2019, 8. [CrossRef]

3. Gielen, D.; Boshell, F.; Saygin, D.; Bazilian, M.D.; Wagner, N.; Gorini, R. The role of renewable energy in the global energy transformation. Energy Strategy Rev. 2019, 24, 38-50. [CrossRef] 
4. Thompson, P. The Agricultural Ethics of Biofuels: The Food vs. Fuel Debate. Agriculture 2012, 2, 339-358. [CrossRef]

5. Cuevas, H.E.; Prom, L.K.; Erpelding, J.E. Tapping the US Sweet Sorghum Collection to Identify Biofuel Germplasm. Sugar Tech 2015, 17, 428-438. [CrossRef]

6. Tesfaye, K. Genetic diversity study of sorghum (Sorghum bicolor (L.) Moenc) genotypes, Ethiopia. Acta Univ. Sapientiae Agric. Environ. 2017, 9, 44-54. [CrossRef]

7. Irving, L. Carbon Assimilation, Biomass Partitioning and Productivity in Grasses. Agriculture 2015, 5, 1116-1134. [CrossRef]

8. Regassa, T.H.; Wortmann, C.S. Sweet sorghum as a bioenergy crop: Literature review. Biomass Bioenergy 2014, 64, 348-355. [CrossRef]

9. Wang, D.; Bean, S.; McLaren, J.; Seib, P.; Madl, R.; Tuinstra, M.; Shi, Y.; Lenz, M.; Wu, X.; Zhao, R. Grain sorghum is a viable feedstock for ethanol production. J. Ind. Microbiol. Biotechnol. 2008, 35, 313-320. [CrossRef]

10. Shakoor, N.; Nair, R.; Crasta, O.; Morris, G.; Feltus, A.; Kresovich, S. A Sorghum bicolor expression atlas reveals dynamic genotype-specific expression profiles for vegetative tissues of grain, sweet and bioenergy sorghums. BMC Plant Biol. 2014, 14, 35. [CrossRef]

11. Murray, S.C.; Rooney, W.L.; Hamblin, M.T.; Mitchell, S.E.; Kresovich, S. Sweet Sorghum Genetic Diversity and Association Mapping for Brix and Height. Plant Genome 2009, 2, 347. [CrossRef]

12. Dicko, M.H.; Gruppen, H.; Traore, A.S.; Voragen, A.G.J.; van Berkel, W.J.H. Sorghum grain as human food in Africa: Relevance of content of starch and amylase activities. Afr. J. Biotechnol. 2006, 5, 384-395.

13. Felderhoff, T.J.; Murray, S.C.; Klein, P.E.; Sharma, A.; Hamblin, M.T.; Kresovich, S.; Vermerris, W.; Rooney, W.L. QTLs for Energy-related Traits in a Sweet $\times$ Grain Sorghum [Sorghum bicolor (L.) Moench] Mapping Population. Crop Sci. 2012, 52, 2040-2049. [CrossRef]

14. Abenavoli, L.; Milanovic, M.; Procopio, A.C.; Spampinato, G.; Maruca, G.; Perrino, E.V.; Mannino, G.C.; Fagoonee, S.; Luzza, F.; Musarella, C.M. Ancient wheats: Beneficial effects on insulin resistance. Minerva Med. 2020. [CrossRef]

15. Disasa, T.; Feyissa, T.; Admassu, B.; Fetene, M.; Mendu, V. Mapping of QTLs Associated with Brix and Biomass-Related Traits in Sorghum Using SSR Markers. Sugar Tech 2018, 20, 275-285. [CrossRef]

16. Makanda, I.; Derera, J.; Tongoona, P.; Sibiya, J. Development of sorghum for bio-energy: A view from the stakeholders and priorities for breeding dual purpose varieties. Afr. J. Agric. Res. 2011, 6, 4477-4486.

17. Prasad, S.; Singh, A.; Jain, N.; Joshi, H.C. Ethanol Production from Sweet Sorghum Syrup for Utilization as Automotive Fuel in India. Energy Fuels 2007, 21, 2415-2420. [CrossRef]

18. Tsuchihashi, N.; Goto, Y. Cultivation of Sweet Sorghum (Sorghum bicolor (L.) Moench) and Determination of its Harvest Time to Make Use as the Raw Material for Fermentation, Practiced during Rainy Season in Dry Land of Indonesia. Plant Prod. Sci. 2004, 7, 442-448. [CrossRef]

19. Kanbar, A.; Shakeri, E.; Alhajturki, D.; Horn, T.; Emam, Y.; Tabatabaei, S.A.; Nick, P. Morphological and molecular characterization of sweet, grain and forage sorghum (Sorghum bicolor L.) genotypes grown under temperate climatic conditions. Plant Biosyst. Int. J. Deal. All Asp. Plant Biol. 2019, 154, 49-58. [CrossRef]

20. Rao, P.S.; Kumar, C.G. Characterization of Improved Sweet Sorghum Cultivars; Springer: New Delhi, India, 2013; ISBN 978-81-322-0783-2.

21. Smith, G.A.; Buxton, D.R. Temperate zone sweet sorghumethanol production potential. Bioresour. Technol. 1993, 43, 71-75. [CrossRef]

22. Windpassinger, S.; Friedt, W.; Frauen, M.; Snowdon, R.; Wittkop, B. Designing adapted sorghum silage types with an enhanced energy density for biogas generation in temperate Europe. Biomass Bioenergy 2015, 81, 496-504. [CrossRef]

23. Ritter, K.B.; McIntyre, C.L.; Godwin, I.D.; Jordan, D.R.; Chapman, S.C. An assessment of the genetic relationship between sweet and grain sorghums, within Sorghum bicolor ssp. bicolor (L.) Moench, using AFLP markers. Euphytica 2007, 157, 161-176. [CrossRef]

24. Lingle, S.E. Sucrose Metabolism in the Primary Culm of Sweet Sorghum During Development. Crop Sci. 1987, 27, 1214-1219. [CrossRef]

25. Cooper, E.A.; Brenton, Z.W.; Flinn, B.S.; Jenkins, J.; Shu, S.; Flowers, D.; Luo, F.; Wang, Y.; Xia, P.; Barry, K.; et al. A new reference genome for Sorghum bicolor reveals high levels of sequence similarity between sweet and grain genotypes: Implications for the genetics of sugar metabolism. BMC Genom. 2019, 20, 420. [CrossRef]

26. Kanbar, A.; Shakeri, E.; Alhajturki, D.; Riemann, M.; Bunzel, M.; Morgano, M.; Stapf, D.; Nick, P. Sweet versus grain sorghum: Differential sugar transport and accumulation are linked with vascular bundle architecture. Ind. Crop. Prod. 2021, in press.

27. Bihmidine, S.; Baker, R.F.; Hoffner, C.; Braun, D.M. Sucrose accumulation in sweet sorghum stems occurs by apoplasmic phloem unloading and does not involve differential Sucrose transporter expression. BMC Plant Biol. 2015, 15, 186. [CrossRef] [PubMed]

28. Hermuth, J.; Kosová, K. Characterization of the first Czech sorghum variety Ruzrok tested in Czech Republic. Czech J. Genet. Plant Breed. 2017, 53, 37-44. [CrossRef]

29. Undersander, D.J.; Lueschen, W.E.; Smith, L.H.; Kaminski, A.R.; Doll, D.J.; Kelling, K.A.; Oplinger, E.S. Sorghum-for syrup. In Alternative Field Crops Manual; University of Wisconsin-Extension, University of Minnesota, Center for the Alternative Plants and Animal Products and the Minnesota Extension Services: Madison, WI, USA; Waseca, MN, USA, 1990.

30. Rao, D.B.; Chamarthy, R.; Karthikeyan, K.; Biswas, P.K.; Rao, S.S.; Kumar, B.S.; Seetharama, N. Sweet Sorghum Cane for Bio-Fuel Production: A SWOT Analysis in Indian Context; National Research Centre for Sorghum: Hyderabad, India, $2004 ;$ p. 500. 
31. Reddy, B.V.S.; Ramesh, S.; Sanjana, P.R.; Ramaiah, B.; Salimath, P.M.; Kachapur, R. Sweet Sorghum: A potential alternate raw material for bio-ethanol and bio-energy. J. Sat Agric. Res. 2005, 46, 79-86.

32. Pearson, K. Note on regression and inheritance in the case of two parents. Proc. R. Soc. Lond. 1895, 58, 240-242. [CrossRef]

33. Hair, J.F.; Anderson, R.E.; Tatham, R.L.; Black, W.C. Multivariate Data Analysis; Englewood Cliffs: Prentice-Hall, NJ, USA, 1995.

34. Sneath, P.H.A.; Sokal, R.R. The estimation of taxonomic resemblance. In Numerical Taxonomy: The Principles and Practice of Numerical Classification; Sneath, P.H.A., Sokal, R.R., Eds.; Freeman: San Francisco, CA, USA, 1973; pp. 129-132. ISBN 0716706970.

35. Godoy, J.G.V.; Tesso, T.T. Analysis of Juice Yield, Sugar Content, and Biomass Accumulation in Sorghum. Crop Sci. 2013, 53, 1288-1297. [CrossRef]

36. Kopecký, M.; Mráz, P.; Kolář, L.; Váchalová, R.; Bernas, J.; Konvalina, P.; Perná, K.; Murindangabo, Y.; Menšík, L. Effect of Fertilization on the Energy Profit of Tall Wheatgrass and Reed Canary Grass. Agronomy 2021, 11, 445. [CrossRef]

37. Mathur, S.; Umakanth, A.V.; Tonapi, V.A.; Sharma, R.; Sharma, M.K. Sweet sorghum as biofuel feedstock: Recent advances and available resources. Biotechnol. Biofuels 2017, 10, 146. [CrossRef]

38. Cifuentes, R.; Bressani, R.; Rolz, C. The potential of sweet sorghum as a source of ethanol and protein. Energy Sustain. Dev. 2014, 21, 13-19. [CrossRef]

39. Wang, M.L.; Zhu, C.; Barkley, N.A.; Chen, Z.; Erpelding, J.E.; Murray, S.C.; Tuinstra, M.R.; Tesso, T.; Pederson, G.A.; Yu, J. Genetic diversity and population structure analysis of accessions in the US historic sweet sorghum collection. Appl. Genet. 2009, 120, 13-23. [CrossRef] [PubMed]

40. Motlhaodi, T.; Geleta, M.; Chite, S.; Fatih, M.; Ortiz, R.; Bryngelsson, T. Genetic diversity in sorghum [Sorghum bicolor (L.) Moench] germplasm from Southern Africa as revealed by microsatellite markers and agro-morphological traits. Genet. Resour. Crop Evol. 2017, 64, 599-610. [CrossRef]

41. Abdi, A.; Bekele, E.; Asfaw, Z.; Teshome, A. Patterns of morphological variation of sorghum (Sorghum bicolor (L.) Moench) landraces in qualitative characters in North Shewa and South Welo, Ethiopia. Hereditas 2002, 137, 161-172. [CrossRef]

42. Deu, M.; Rattunde, F.; Chantereau, J. A global view of genetic diversity in cultivated sorghums using a core collection. Genome 2006, 49, 168-180. [CrossRef] [PubMed]

43. Rani, C.; Umakanth, A.V. Genetic variation and trait inter-relationship in F1 Genetic variation and trait inter-relationship in F1 hybrids of sweet sorghum(Sorghum bicolor (L.) Moench). J. Trop. Agric. 2012, 50, 80-83.

44. Wang, M.; Xin, Z.; Tonnis, B.; Farrell, G.; Pinnow, D.; Chen, Z.; Davis, J.; Yu, J.; Hung, Y.-C.; Pederson, G.A. Evaluation of Sweet Sorghum as a Feedstock by Multiple Harvests for Sustainable Bioenergy Production. J. Sustain. Bioenergy Syst. 2012, 2, $122-137$. [CrossRef]

45. Rooney, W.L.; Blumenthal, J.; Bean, B.; Mullet, J.E. Designing sorghum as a dedicated bioenergy feedstock. Biofuels Bioprod. Bioref. 2007, 1, 147-157. [CrossRef]

46. Rao, S.S.; Patil, J.V.; Umakanth, A.V.; Mishra, J.S.; Ratnavathi, C.V.; Prasad, G.S.; Rao, B.D. Comparative Performance of Sweet Sorghum Hybrids and Open Pollinated Varieties for Millable Stalk Yield, Biomass, Sugar Quality Traits, Grain Yield and Bioethanol Production in Tropical Indian Condition. Sugar Tech 2013, 15, 250-257. [CrossRef]

47. Kante, M.; Rattunde, F.; Nébié, B.; Sissoko, I.; Diallo, B.; Diallo, A.; Touré, A.; Weltzien, E.; Haussmann, B.I.G.; Leiser, W.L. Sorghum Hybrids for Low-Input Farming Systems in West Africa: Quantitative Genetic Parameters to Guide Hybrid Breeding. Crop Sci. 2019, 59, 2544-2561. [CrossRef]

48. Hermuth, J.; Janovská, D.; Čepková, P.H.; Ustak, S.; Strašil, Z.; Dvoráková, Z. Sorghum and Foxtail Millet-Promising Crops for the Changing Climate in Central Europe. In Alternative Crops and Cropping Systems; Konvalina, P., Ed.; IntechOpen: London, UK, 2016; ISBN 978-953-51-2279-1.

49. Almodares, A.; Mostafafi Darany, S.M. Effects of planting date and time of nitrogen application on yield and sugar content of sweet sorghum. J. Environ. Biol. 2006, 27, 601-605. [PubMed]

50. Alhajturki, D.; Al Jamali, M.; Kanbar, A. Genetic variation of sorghum (Sorghum bicolor L. Moench) varieties assessed by ISSR markers. Adv. Environ. Biol. 2011, 5, 3504-3510.

51. Shukla, S.; Felderhoff, T.J.; Saballos, A.; Vermerris, W. The relationship between plant height and sugar accumulation in the stems of sweet sorghum (Sorghum bicolor (L.) Moench). Field Crops Res. 2017, 203, 181-191. [CrossRef]

52. Murray, S.C.; Sharma, A.; Rooney, W.L.; Klein, P.E.; Mullet, J.E.; Mitchell, S.E.; Kresovich, S. Genetic Improvement of Sorghum as a Biofuel Feedstock: I. QTL for Stem Sugar and Grain Nonstructural Carbohydrates. Crop Sci. 2008, 48, 2165-2179. [CrossRef]

53. Shiringani, A.L.; Frisch, M.; Friedt, W. Genetic mapping of QTLs for sugar-related traits in a RIL population of Sorghum bicolor L. Moench. Appl. Genet. 2010, 121, 323-336. [CrossRef]

54. Naoura, G.; Sawadogo, N.; Atchozou, E.A.; Emendack, Y.; Hassan, M.A.; Reoungal, D.; Amos, D.N.; Djirabaye, N.; Tabo, R.; Laza, $\mathrm{H}$. Assessment of agro-morphological variability of dry-season sorghum cultivars in Chad as novel sources of drought tolerance. Sci. Rep. 2019, 9, 19581. [CrossRef] [PubMed]

55. McKinley, B.; Rooney, W.; Wilkerson, C.; Mullet, J. Dynamics of biomass partitioning, stem gene expression, cell wall biosynthesis, and sucrose accumulation during development of Sorghum bicolor. Plant J. 2016, 88, 662-680. [CrossRef]

56. Morey, S.R.; Hashida, Y.; Ohsugi, R.; Yamagishi, J.; Aoki, N. Evaluation of performance of sorghum varieties grown in Tokyo for sugar accumulation and its correlation with vacuolar invertase genes SbInv1 and SbInv2. Plant Prod. Sci. 2018, 21, 328-338. [CrossRef] 
57. Guan, Y.-a.; Wang, H.-1.; Qin, L.; Zhang, H.-w.; Yang, Y.-b.; Gao, F.-j.; Li, R.-y.; Wang, H.-g. QTL mapping of bio-energy related traits in Sorghum. Euphytica 2011, 182, 431-440. [CrossRef]

58. Ni, Z.; Kim, E.-D.; Ha, M.; Lackey, E.; Liu, J.; Zhang, Y.; Sun, Q.; Chen, Z.J. Altered circadian rhythms regulate growth vigour in hybrids and allopolyploids. Nature 2009, 457, 327-331. [CrossRef] [PubMed]

59. Hoffmann-Thoma, G.; Hinkel, K.; Nicolay, P.; Willenbrink, J. Sucrose accumulation in sweet sorghum stem internodes in relation to growth. Physiol. Plant. 1996, 97, 277-284. [CrossRef]

60. Li, Y.; Tu, M.; Feng, Y.; Wang, W.; Messing, J. Common metabolic networks contribute to carbon sink strength of sorghum internodes: Implications for bioenergy improvement. Biotechnol. Biofuels 2019, 12, 274. [CrossRef] [PubMed]

61. Murray, S.C.; Rooney, W.L.; Mitchell, S.E.; Sharma, A.; Klein, P.E.; Mullet, J.E.; Kresovich, S. Genetic Improvement of Sorghum as a Biofuel Feedstock: II. QTL for Stem and Leaf Structural Carbohydrates. Crop Sci. 2008, 48, 2180-2193. [CrossRef]

62. Shiringani, A.L.; Friedt, W. QTL for fibre-related traits in grain $\times$ sweet sorghum as a tool for the enhancement of sorghum as a biomass crop. Appl. Genet. 2011, 123, 999-1011. [CrossRef]

63. Luo, F.; Pei, Z.; Zhao, X.; Liu, H.; Jiang, Y.; Sun, S. Genome-Wide Association Study for Plant Architecture and Bioenergy Traits in Diverse Sorghum and Sudangrass Germplasm. Agronomy 2020, 10, 1602. [CrossRef]

64. Gutjahr, S.; Cl Ment-Vidal, A.; Soutiras, A.; Sonderegger, N.; Braconnier, S.; Dingkuhn, M.L.; Luquet, D. Grain, sugar and biomass accumulation in photoperiod-sensitive sorghums. II. Biochemical processes at internode level and interaction with phenology. Funct. Plant Biol. 2013, 40, 355-368. [CrossRef]

65. Lin, Y.R.; Schertz, K.F.; Paterson, A.H. Comparative analysis of QTLs affecting plant height and maturity across the Poaceae, in reference to an interspecific sorghum population. Genetics 1995, 141, 391. [CrossRef]

66. Burks, P.S.; Kaiser, C.M.; Hawkins, E.M.; Brown, P.J. Genomewide Association for Sugar Yield in Sweet Sorghum. Crop Sci. 2015, 55, 2138-2148. [CrossRef]

67. Beuningen, L.T.; Busch, R.H. Genetic Diversity among North American Spring Wheat Cultivars: I. Analysis of the Coeffecient of Parentage Matrix. Crop Sci. 1997, 37, 570-579. [CrossRef]

68. Perrino, E.V.; Wagensommer, R.P. Crop Wild Relatives (CWR) Priority in Italy: Distribution, Ecology, In Situ and Ex Situ Conservation and Expected Actions. Sustainability 2021, 13, 1682. [CrossRef]

69. Souza, E.; Sorrells, M.E. Relationships among 70 North American Oat Germplasms: I. Cluster Analysis Using Quantitative Characters. Crop Sci. 1991, 31, 599-605. [CrossRef]

70. Sinha, S.; Kumaravadivel, N. Understanding Genetic Diversity of Sorghum Using Quantitative Traits. Scientifica 2016, $2016,3075023$. [CrossRef] [PubMed]

71. Mindaye, T.T.; Mace, E.S.; Godwin, I.D.; Jordan, D.R. Heterosis in locally adapted sorghum genotypes and potential of hybrids for increased productivity in contrasting environments in Ethiopia. Crop J. 2016, 4, 479-489. [CrossRef] 